\title{
A COMMON-SENSE DEFINITION OF "COMMON UNDERSTANDING"
}

\section{SAM NuNN $\dagger$}

Professor Koplow is to be commended for authoring a comprehensive and especially cogent analysis of the debate over the Reagan Administration's 1985 reinterpretation of the 1972 Anti-Ballistic Missile (ABM) Treaty. His article and the accompanying written commentaries provided by legal scholars and policy participants should make an important contribution to public understanding of the basic constitutional principles which were upheld in the course of this protracted confrontation between the Executive and Legislative Branches of our government.

In his article, Professor Koplow appropriately focuses on the broader legal dimensions of the reinterpretation dispute. In so doing, he underscores the extent to which the issue raised by the reinterpretation went far beyond this particular treaty and its application to the Strategic Defense Initiative (SDI) program. What was fundamentally at stake, he notes, was the important role assigned to the Senate under the Constitution as a co-equal partner with the President in the making of treaties, and the reliability of the United States as a negotiating partner in the international arena.

Professor Koplow's well-written and well-reasoned article performs a particularly valuable service in highlighting what ultimately became the bottom-line issue in this disagreement: whether a specific "means test" proposed by senior legal officials in the Reagan Administration had to be satisfied before Executive Branch communications to the Senate during ratification proceedings would be treated as binding on all future Presidents under domestic law.

In an April 9, 1987 Justice Department opinion written by Assistant Attorney General Charles Cooper, the Justice Department acknowledged that in certain instances the President would be "estopped" from making an interpretation that conflicted with what the Senate was told at the time of ratification:

If . $\therefore$ the ratification record unequivocally shows that the President presented the treaty to the Senate based on spe-

† United States Senator (D-Ga.); Chairman, Senate Armed Services Committee. 
cific, official representations regarding the meaning of an ambiguous provision, that the Senate regarded that understanding as important to its consent, and that the Senate relied on the representations made by the Executive Branch in approving the treaty (and thus in refraining from attaching a formal reservation setting forth the understanding), we believe that the President would, in effect, be estopped from taking a contrary position in his subsequent interpretation of the treaty, just as he would be bound by a formal reservation or understanding passed by the Senate to the same effect. ${ }^{1}$

This recognition that Executive Branch testimony during the ratification proceedings could - at least in certain circumstances-be binding on future Presidents' positions appeared to contradict testimony a month earlier by the State Department Legal Adviser, Judge Abraham Sofaer. Judge Sofaer testified that "when it [the Senate] gives its advice and consent to a treaty, it is to the treaty that was made, irrespective of the explanations it is provided." This proposition became known as the "Sofaer Doctrine."

The Justice Department's acknowledgment that ratification testimony would be binding on future Presidents was endorsed one year later in a March 17, 1988 letter to Senator Lugar from White House Gounsel Arthur Culvahouse. In the Culvahouse letter, the White House contended that Presidents would be bound by Executive Branch representations to the Senate at the time of ratification-but only if those communications met a specific "means test." According to Culvahouse, Executive Branch testimony should be treated as binding only it if was: (1) "authoritatively communicated"; (2) "clearly intended"; and (3) "generally understood and relied upon by the Senate in its advice and consent to ratification."s

For advocates of reinterpreting the ABM Treaty, the attraction of the Culvahouse means test was that it afforded the Executive Branch a virtually unlimited set of options for disavowing the binding effect of ratification testimony presented by previous administrations. As the New York Times noted, "[s]ince it's hard to know what this mumbo-

I Memo from Assistant Attorney General Charles Cooper to State Department Legal Advisor Abraham Sofaer (Apr. 9, 1987).

2 The ABM Treaty and the Constitution: Joint Hearings Before the Senate Comm. on Foreign Relations and the Senate Comm. on the Judiciary, 100th Cong., 1st Sess. 130 (1987).

${ }^{3}$ Letter from White House Counsel Arthur B. Culvahouse to Senator Richard D. Lugar 3 (Mar. 17, 1988), reprinted in Senate Comm. on Foreign Relations, The INF Treaty, S. Exec. ReP. No. 15, 100th Cong., 2d Sess. 438, 440 (1988). 
jumbo means, Presidents would be free to do with treaties as they wish."'

If a future President wanted to evade the obligations flowing from a particular treaty interpretation presented to the Senate at the time of ratification, that administration could declare that the Executive Branch official who presented the testimony in question was not "authoritative." The requirement of authoritativeness appears commonsensical at first blush, and the Senate agreed in principle that it could not expect to rely on representations which were not authoritative. However, efforts by the Reagan Administration to discount as "nonauthoritative" 1972 ABM Treaty testimony by certain senior Nixon Administration officials-including the Secretary of Defense and the Director of Defense Research and Engineering-revealed the proposed rule's potential for abuse.

If a future President preferred not to try to exploit the "authoritative witness" loophole, that administration could turn to either of the two other escape clauses incorporated in the Culvahouse/Sofaer criteria. For example, a future President could assert that particular testimony could be disregarded because it was not "generally understood" by Senators who voted on the treaty. How would one determine what may or may not have been in the minds of Senators who heard the testimony or reviewed the hearing prints? Alternatively, that administration could claim-as was done in the ABM case-that the ratification record does not provide sufficient indication that all or most Senators "relied upon" a particular body of testimony in voting on the treaty. Again, how is one to determine what testimony was or was not on the minds of particular Senators at the time they cast their votes?

If the Senate had accepted all three components of the Culvahouse means test and carried it to its logical conclusion, Senators would have had no recourse during the INF ratification proceedings but to have both affirmed that each witness was "authoritative" (as we in fact did), and to have paused after each bit of testimony and made it a matter of record that they regarded each statement as clearly intended, generally understood, and one on which they would rely. Such an approach would not only have placed an inordinate burden on the Senate, it also would have made a mockery of Senate ratification proceedings.

In lieu of the straightjacket which would have been imposed on the Senate by the Culvahouse criteria, the Senate adopted a "treaty interpretation amendment" to the resolution of ratification accompany-

4he Doctrine or the Treaty?, N. Y. Times, May 5, 1988, at A30, col. 1 (editorial). 
ing the INF Treaty which incorporated a more comprehensive and common-sense definition, based on the treaty clauses of the Constitution, of what constituted binding testimony. The provision, known as the Byrd-Biden Amendment, provided that the INF Treaty must be interpreted by future Presidents "in accordance with the common understanding of the Treaty shared by the President and the Senate at the time the Senate gave its advice and consent to ratification." The Amendment declared that this "common understanding" was based on:

(A) First, the text of the Treaty and the provisions of this resolution of ratification; and

(B) Second, the authoritative representations which were provided by the President and his representatives to the Senate and its Committees, in seeking Senate consent to ratification, insofar as such representations were directed to the meaning and legal effect of the text of the Treaty. ${ }^{6}$

During the Senate debate on the Byrd-Biden Amendment, Senator Specter argued that it should be defeated because, inter alia, the amendment's definition of what constituted a "common understanding" of the treaty's meaning did not enumerate the three criteria of the Culvahouse means test. ${ }^{7}$ Rejecting this and other criticisms, the Senate on May 26, 1988 adopted the Biden-Byrd Amendment by an overwhelming and bipartisan vote of $72-27 .{ }^{8}$

Although supporters of the Byrd-Biden Amendment thought that this vote had resolved the issue, Senator Specter pursued the debate further the following day. The Senator urged an amendment to qualify the Byrd-Biden Amendment by adding the following sentence:

Such common understanding means a shared interpretation which is both authoritatively communicated to the Senate by the Executive and clearly intended, generally understood, and relied upon by the State [sic; should be "Senate"] in its advice and consent to ratification. ${ }^{9}$

Senator Specter performed an important service in ensuring that the Culvahouse means test would be put to a clear-cut vote. Following an extensive debate in which the opposing sides forcefully and intelligently argued their respective cases, the Senate rejected the amend-

s 134 Cong. Rec. S6725 (daily ed. May 20, 1988).

${ }^{6} I d$.

7 See id. at S6778-80.

8 See id. at S6783-84.

- 134 Cong. Rec. S6884 (daily ed. May 27, 1988). 
ment-and with it what remained of the Sofaer Doctrine-by a bipartisan vote of $67-30 .^{10}$

With the passage of time, I am confident that the Senate's rejection of the Sofaer Doctrine will be regarded as one of its finest hours. As previously noted, however, more was at stake in this long struggle than the Senate's constitutional powers and responsibilities. For had the precedent been established that the original meaning of a treaty could be unilaterally changed by a future President, our Nation's reliability as a negotiating partner could have been called into question, with destructive consequences for the conduct of United States foreign policy. Professor Koplow's article will help ensure that these lessons are not forgotten. 


$$
\text { 。 }
$$

